\title{
The role of the palatine tonsils in the pathogenesis and treatment of psoriasis
}

\author{
S.L. Sigurdardottir, ${ }^{1}$ R.H. Thorleifsdottir, ${ }^{1}$ H. Valdimarsson ${ }^{1}$ and A. Johnston ${ }^{2}$ \\ ${ }^{1}$ Department of Immunology, Landspitali-University Hospital, Reykjavik, Iceland \\ ${ }^{2}$ Department of Dermatology, University of Michigan, Ann Arbor, MI, U.S.A.
}

\section{Summary}

\section{Correspondence \\ Andrew Johnston. \\ E-mail: andjoh@med.umich.edu}

\section{Accepted for publication}

3 August 2012

\section{Funding sources}

This work was funded in part by grants from The Babcock Endowment, National Psoriasis

Foundation U.S.A. and The American Skin

Association to A.J., and from The Icelandic

Research Fund, Landspitali Hospital Research Fund and The Research Fund of the University of

Iceland for Doctoral Studies to S.L.S.

\section{Conflicts of interest}

None declared.

DOI 10.1111/j.1365-2133.2012.11215.x
Psoriasis is a common chronic skin disease with strong genetic associations and environmental triggers. Patients with psoriasis develop sore throats much more frequently than nonpsoriatic individuals and it is well documented that streptococcal throat infections can trigger the onset of psoriasis, and such infections cause exacerbation of chronic psoriasis. It is now generally accepted that psoriatic lesions are caused by abnormal reactivity of specific $\mathrm{T}$ lymphocytes in the skin. However, it has been shown in recent years that activation of specific immunity is always preceded by activation of nonspecific innate immune mechanisms, and that abnormalities in the innate immune system can cause dysregulation in specific immune responses. Here we explore the possible immune mechanisms that are involved in the link between infection of the tonsils and this inflammatory skin disease. Moreover, we survey the literature and discuss the suitability of tonsillectomy as a treatment for psoriasis.

\section{Psoriasis, a T-cell-mediated autoimmune disease}

Psoriasis is a common chronic inflammatory skin disease, most often characterized by thickened erythematous scaly plaques, and appears in a variety of forms with distinct characteristics. The most common form, psoriasis vulgaris, affects $1-3 \%$ of the Caucasian population, ${ }^{1}$ usually persists - with $40 \%$ developing seronegative arthritis - and has a very negative impact on quality of life. ${ }^{2}$ Psoriasis is generally regarded as a T-cellmediated autoimmune disease, ${ }^{3-5}$ with treatments targeting $\mathrm{T}$ cells being very effective; ${ }^{6,7}$ indeed, blocking of T-cell entry into the epidermis prevents development of hyperplasia in a mouse model of psoriasis. ${ }^{8}$ There is considerable literature in support of psoriasis being driven by $\mathrm{T}$ cells recognizing peptide antigens (reviewed in Valdimarsson et al. ${ }^{9}$ ). T cells from patients with psoriasis show increased responses to homologous peptides from streptococcal $\mathrm{M}$ proteins ${ }^{10,11}$ and human epidermal keratins; ${ }^{10,12,13}$ thus, it is possible that psoriasis may occur as a consequence of $\mathrm{T}$ cells cross-reacting with epitopes from streptococcal $\mathrm{M}$ proteins and human keratins., The palatine tonsils might play a major role in psoriasis as they are a common site for streptococcal infections and, as immune sentries loaded with antigen-presenting cells and $\mathrm{T}$ cells, are likely a major site for $\mathrm{T}$-cell priming against such antigens. Here we detail how the immune function of the tonsils could lead to the initiation and exacerbation of psoriasis and we survey potential interventions.

\section{The tonsils, immunological sentries of the pharynx}

The mucosal surfaces of the mouth, throat and upper respiratory tract are the first major barrier protecting the host from potentially invading microorganisms, and integral to this defence are the tonsils, which provide a protective immunological ring (Waldeyer's ring) at the openings of both the digestive and respiratory tracts. ${ }^{14}$ The palatine tonsils have a surface lined by a stratified squamous epithelium that extends into deep and branched crypts, increasing their total surface area. The surface of the crypts is lined with a reticulated epithelium, which in parts may be only one cell thick. The reticulated tonsil epithelium has a unique cellular composition where epithelial cells, stromal cells, intraepithelial lymphocytes, dendritic cells (DCs), neutrophils and macrophages are all situated in close proximity, which is ideal for productive antigen sampling. In 
the subepithelial space are B-cell-rich lymphoid follicles that foster the development of memory B cells and antibody producing plasma cells, a process that requires the interaction of a number of B-cell, T-cell and DC subsets. ${ }^{15}$ Six phenotypes of DC have been identified in the tonsils, ${ }^{16,17}$ each with a different location and function. DCs are particularly adept at antigen sampling and processing and presentation of peptide antigens, and influence the $\mathrm{T}$ helper 1 (Th1)/Th2/Th17 balance of T-cell-mediated responses. ${ }^{18}$

\section{The involvement of streptococci in psoriasis}

The most frequent tonsil diseases are recurrent infections and abnormal enlargement of the tonsils (hypertrophy), which may result in the need for tonsillectomy. Streptococcus pyogenes infections are associated with acute and recurrent throat infections, ${ }^{19,20}$ while Haemophilus influenzae infections are thought to stimulate hypertrophic responses. ${ }^{21}$ Throat infection with $\beta$-haemolytic streptococci is the only well-defined external trigger that has been convincingly associated with initiation and acute exacerbation of psoriasis. ${ }^{22-26}$ This association was corroborated in a prospective study that concluded that patients with psoriasis reported a sore throat 10 times more often than household controls, and that streptococcal throat infections can cause exacerbation of chronic plaque psoriasis. ${ }^{24}$ Furthermore, $\boldsymbol{\alpha}$-streptococci are likely to have a role in pustulosis palmaris et plantaris (PPP), a chronic, recurrent, inflammatory skin disease restricted to the palms and soles. ${ }^{27}$ These two inflammatory skin diseases appear to benefit from tonsillectomy, ${ }^{28-30}$ suggesting the importance of the palatine tonsils in inflammatory diseases outside the throat. Tonsils from individuals with PPP differ from recurrently infected tonsils with regard to histology and the expression of skin homing molecules by $\mathrm{T}$ cells. Furthermore, the size of the $\mathrm{T}$-cell area in tonsils has been associated with skin improvement after tonsillectomy. ${ }^{30}$ In this respect, we have recently demonstrated that, compared with nonpsoriatic individuals, tonsils from patients with psoriasis contain an increased frequency of $\mathrm{T}$ cells with skin homing potential (Sigurdardottir, manuscript in preparation). Moreover, superantigens from $\beta$-haemolytic streptococci have been demonstrated to enhance T-cell expression of cutaneous lymphocyte-associated antigen (CLA), ${ }^{31,32}$ a carbohydrate moiety expressed on $80 \%$ of $\mathrm{T}$ cells in the skin, ${ }^{33}$ and the frequency of CLA+CD8 $+\mathrm{T}$ cells in the blood of patients with psoriasis correlates with their disease severity. ${ }^{34}$ The importance of specific effector/memory $\mathrm{T}$ cells is now generally recognized in psoriasis, ${ }^{4}$ but it remains to be elucidated why and where the effector $\mathrm{T}$ cells are activated. In this regard, the innate immune response of the tonsils may play a crucial role in the instigation and subsequent regulation of the T-cell-mediated adaptive immune response. Thus, aberrant tonsil responses to streptococcal infection could lead to altered T-cell expansion and trafficking to the skin where they induce an inflammatory response that initiates the psoriasis plaque. This is further supported by the fact that similar oligoclonal $\mathrm{T}$ cells have been isolated from tonsils and psoriatic plaques of the same individual, ${ }^{35}$ with disease remission following tonsillectomy. ${ }^{35}$

\section{The potential of tonsillectomy for the treatment of psoriasis}

Almost a century ago, Winfield ${ }^{36}$ presented a series of six case reports that first drew attention to the occurrence of psoriasis following inflammation of the tonsils. $\beta$-Haemolytic streptococcus was later identified as the infectious agent, ${ }^{20,23,37}$ leading to the onset of guttate psoriasis, or exacerbation of chronic plaque psoriasis.

Streptococci are not fully eradicated with antibiotics such as penicillin or erythromycin that do not penetrate host cells, ${ }^{38}$ as they are facultative intracellular bacteria ${ }^{39,40}$ unaffected by conventional antibiotics. Rifampicin and clindamycin are also active intracellularly ${ }^{38}$ and eliminate both extra- and intracellular streptococci; ${ }^{41-44}$ however, even treatment with antibiotics is likely to have only a temporary benefit, as about $20 \%$ of healthy, asymptomatic individuals carry $\beta$-haemolytic streptococci in their throat, ${ }^{24}$ making it likely that the bacterium recolonizes the throat of the patients after cessation of treatment. With respect to the treatment of psoriasis with antibiotics, there is a lack of adequately controlled clinical trials (see Owen et al. ${ }^{45}$ ).

A search of the PubMed database using the search terms 'psoriasis', 'tonsils' and 'tonsillectomy' revealed 71 articles from 1960 to 2012. After limiting our search to those studies on 'chronic plaque psoriasis' or 'guttate psoriasis' or 'psoriasis vulgaris', excluding 'palmoplantar pustulosis' or 'pustulosis palmaris et plantaris', and following up citations within these publications, we noted that there exist 12 original case reports or studies on the effect of tonsillectomy on psoriasis (Table 1). In the first report, Whyte and Baughman ${ }^{46}$ described the improvement of psoriasis and decrease in antistreptolysin $\mathrm{O}$ titres following tonsillectomy of three patients with guttate psoriasis. This was followed by the first controlled trial, a 1967 report from Germany ${ }^{47}$ that described 92 patients with psoriasis with chronic tonsillitis, of whom 56 underwent tonsillectomy whereupon 34 (61\%) improved and 22 (39\%) appeared unchanged. This compares with the control group of 36 patients with psoriasis who did not have a tonsillectomy, of whom 8 (22\%) improved and $28(78 \%)$ were unchanged. The authors did not give details of whether the control group was matched for age and sex, nor did they use a quantitative scoring system for disease severity.

Later, Nyfors et al. ${ }^{48}$ conducted an uncontrolled retrospective study, which examined the effect of tonsillectomy on 74 young (mean age $14 \cdot 2$ years) patients with psoriasis vulgaris that proved to be refractory to topical treatments. During the follow-up period (mean 4.5 years), 32\% of patients remained clear of psoriasis, $39 \%$ had a considerable improvement, $22 \%$ were unchanged and $7 \%$ worsened. Another case report ${ }^{49}$ describes the effect of tonsillectomy on two young sisters with guttate psoriasis that developed 1 week after catching a cold and severe sore throat. Interestingly, both sisters carried the 
Table 1 A summary of all case reports and studies to date detailing the effects of tonsillectomy on psoriasis

\begin{tabular}{|c|c|c|c|c|c|c|}
\hline Authors & Country, year & $\begin{array}{l}\text { Number } \\
\text { in study }\end{array}$ & Disease & $\begin{array}{l}\text { Age range } \\
\text { (mean) }\end{array}$ & Outcome & $\begin{array}{l}\text { Follow-up } \\
\text { period }\end{array}$ \\
\hline Whyte and Baughman ${ }^{46}$ & U.S.A., 1964 & 3 & Guttate psoriasis & $15-23(20)$ & $\begin{array}{l}\text { 'Occasional plaques' after } \\
\text { tonsillectomy }\end{array}$ & 1 year \\
\hline Cepicka and Tielsch ${ }^{47}$ & Germany, 1967 & 92 & $\begin{array}{l}\text { Psoriasis associated } \\
\text { with infection }\end{array}$ & NR & $\begin{array}{l}\text { Symptom free in } 61 \% \text { after } \\
\text { tonsillectomy, vs. } 8 \% \text { in } \\
\text { nontonsillectomized group }\end{array}$ & $2-5$ years \\
\hline Nyfors et al. ${ }^{48}$ & Denmark, 1976 & 74 & Psoriasis vulgaris & $4-33(14 \cdot 2)$ & $\begin{array}{l}\text { All lesions cleared in } 32 \% \text {, } \\
\text { 'considerable improvement' } \\
\text { in } 39 \% \text {, unchanged in } 22 \% \text {, } \\
\text { worsened in } 7 \%\end{array}$ & $\begin{array}{l}4 \cdot 5 \text { years } \\
(7-204 \\
\text { months })\end{array}$ \\
\hline Saita et al. ${ }^{49}$ & Japan, 1979 & 2 & Guttate psoriasis & 7,11 & $\begin{array}{l}\text { Both 'cleared almost } \\
\text { completely' within } 2 \text { months } \\
\text { of tonsillectomy }\end{array}$ & NR \\
\hline Hone et al. ${ }^{51}$ & Ireland, 1996 & 13 & $\begin{array}{l}6 \text { Guttate psoriasis } \\
7 \text { Chronic plaque } \\
\text { psoriasis }\end{array}$ & $6-28(17)$ & $\begin{array}{l}\text { Guttate: } 5 / 6 \text { cleared, } 1 / 6 \\
\text { improved } \\
\text { Plaque: } 2 / 7 \text { cleared, } 2 / 7 \\
\text { improved, } 3 / 7 \text { unchanged }\end{array}$ & $\begin{array}{l}6-52(26) \\
\text { months }\end{array}$ \\
\hline Kataura and Tsubota ${ }^{52}$ & Japan, 1996 & 35 & Psoriasis vulgaris & NR & $\begin{array}{l}\text { 'Remarkably effective' } 29 \% \text {, } \\
\text { 'effective' } 20 \% \text {, 'partially } \\
\text { effective' } 11 \% \text {, unchanged } \\
31 \% \text {, worsened } 9 \%\end{array}$ & 3 months \\
\hline Rosenberg et al. ${ }^{53}$ & U.S.A., 1998 & 14 & NR & NR & $\begin{array}{l}\text { All lesions cleared in } 9 / 14 \\
\text { cases, improvement in } 5 / 14\end{array}$ & NR \\
\hline McMillin et al. ${ }^{54}$ & U.S.A., 1999 & 2 & $\begin{array}{l}1 \text { Guttate psoriasis } \\
1 \text { Severe psoriasis }\end{array}$ & $\begin{array}{l}11 \\
5\end{array}$ & All lesions cleared & 16 months \\
\hline Ozawa et al. ${ }^{55}$ & Japan, 1999 & 385 & $\begin{array}{l}\text { Generalized pustular } \\
\text { psoriasis }\end{array}$ & NR & 'Effective' in $16 \cdot 7 \%$ of cases & NR \\
\hline Takahara et al. ${ }^{56}$ & Japan, 2001 & 7 & Psoriasis (?) & $9-46(23)$ & $\begin{array}{l}\text { All lesions cleared in } 3 / 7 \text {, } \\
80 \% \text { of lesions cleared in } \\
2 / 7 \text {, no change in } 2 / 7\end{array}$ & $2-9$ years \\
\hline Diluvio et al. ${ }^{35}$ & Germany, 2006 & 3 & $\begin{array}{l}\text { Recalcitrant nonpustular } \\
\text { chronic plaque psoriasis } \\
\text { with guttate flares }\end{array}$ & $21,29,33$ & $\begin{array}{l}\text { Complete remission (Psoriasis } \\
\text { Area and Severity } \\
\text { Index score }=0 \text { ) }\end{array}$ & $>3$ years \\
\hline Thorleifsdottir et al. ${ }^{29}$ & Iceland, 2012 & 29 & $\begin{array}{l}\text { Chronic psoriasis } \\
\text { with history } \\
\text { of exacerbation after } \\
\text { sore throat }\end{array}$ & $19-54(35 \cdot 5)$ & $\begin{array}{l}\text { 13/15 (86\%) with 30-90\% } \\
\text { clinical improvement. No } \\
\text { consistent clinical changes } \\
\text { in control group }\end{array}$ & 2 years \\
\hline
\end{tabular}

NR, not reported.

human leucocyte antigen-B37 allele, which is part of one of the psoriasis risk haplotypes. ${ }^{50}$ In both cases the skin lesions cleared almost completely within 2 months of tonsillectomy; however, the treatment was complicated by the postoperative use of antibiotics and topical corticosteroid cream.

Over 10 years later, Hone et al. ${ }^{51}$ reported an uncontrolled prospective study on 13 patients (mean age 17 years) with recalcitrant psoriasis. The group consisted of six patients with guttate psoriasis and seven with chronic plaque psoriasis. From the group as a whole, seven patients showed complete clearance and three showed significantly improved psoriasis following tonsillectomy, with noticeable improvement within a month. The data for the patients with guttate psoriasis was more impressive, as the disease cleared in five out of six patients, with the remaining patient having a significant improvement. The authors claim that the patients served as their own controls, yet they omitted to acknowledge that patients with guttate psoriasis might have spontaneous remissions. In the same year, a Japanese study including 35 patients with psoriasis vulgaris ${ }^{52}$ reported that $49 \%$ of the patients showed a clear improvement in their clinical symptoms following tonsillectomy, which was more effective for women ( $84 \%$ having some degree of improvement) than men (31\%). It was also more effective in younger patients: $83 \%$ of those under the age of 20 years showed some degree of improvement, which fell to $68 \%$ in the under-30s category.

In 1998, Rosenberg et al. ${ }^{53}$ reported clearance of psoriasis in nine of 14 patients following tonsillectomy, and a significant improvement in the remaining five. All 14 patients had evidence of streptococcal colonization that could not be resolved by antibiotics. A year later, McMillin et al. ${ }^{54}$ gave details of two case reports. The first was a 5-year-old girl 
who had severe early-onset psoriasis, a history of enlarged tonsils and one episode of streptococcal pharyngitis. The second was an 11-year-old boy with early-onset guttate psoriasis and recurrent streptococcal pharyngitis. As with the earlier report from Hone et al., ${ }^{51}$ the children showed a marked improvement in their psoriasis as early as 1 month after adenotonsillectomy and both were clear of psoriasis at a 16month follow-up examination. In the same year, Ozawa et al. ${ }^{55}$ conducted a multicentre retrospective study based on physician questionnaires, which included 385 cases of generalized pustular psoriasis. They reported that tonsillectomy was 'effective' for $16 \cdot 7 \%$ of the patients. A more recent report came from Japan in 2001, where seven patients with psoriasis underwent tonsillectomy and were followed up for 2-9 years after surgery. ${ }^{56}$ All lesions had cleared in three patients and $80 \%$ of lesions cleared in two patients, with no changes in the disease of the remaining two. Of the five patients showing improvement, four had a history of tonsillitis making their skin lesions worse. The group of Prinz followed three patients with recalcitrant chronic plaque psoriasis with guttate flares for 3 years after tonsillectomy and reported complete remission. ${ }^{35}$ Moreover, analysis of T-cell receptor beta-chain variable region gene rearrangements suggested that $\mathrm{T}$ cells from the same $\mathrm{T}$-cell clones were simultaneously present within the skin and tonsils of these patients. $^{35}$

These data are compelling but case reports carry limitations inherent in their study design (or lack thereof), given that the patients are managed in a noncontrolled environment, the observation is based on an individual or small group, which may not reflect a larger population, and some of the effects noted may have simply arisen from the natural history of the disease, rather than the treatment. Thus, we recently completed a prospective, controlled, observer-blinded trial ${ }^{29}$ involving 29 patients with chronic psoriasis and a history of exacerbation after sore throat, who were randomly assigned to tonsillectomy $(\mathrm{n}=15)$ or control $(\mathrm{n}=14)$ groups and were followed for 2 years. Of this group, 13 patients (86\%) showed sustained improvement after tonsillectomy ranging from $30 \%$ to $90 \%$ reduction in disease severity. In addition to clinical follow-up, we assessed blood $\mathrm{T}$ cell responses to pools of short peptides derived from human epidermal keratins and streptococcal $\mathrm{M}$ proteins, and found a close correlation between the degree of clinical improvement in individual patients and reduction in the frequency of peptide-reactive skin-homing $\mathrm{T}$ cells in the blood. ${ }^{29}$ No corresponding clinical or immunological changes were observed among the control group.

\section{Outlook}

All of the studies and case reports reviewed here conclude that tonsillectomy may be of considerable benefit to selected patients. Psoriasis is influenced by multiple genetic polymorphisms and environmental factors, ${ }^{57}$ resulting in a range of disease severity and course among patients, which is likely reflected in the response to treatment. ${ }^{58,59}$ Some patients with recalcitrant guttate or chronic plaque psoriasis, particularly those with early-onset psoriasis that is exacerbated by streptococcal tonsillitis, appear to have long-term remissions following tonsillectomy. In our recent study, ${ }^{29}$ tonsillectomized patients not only benefited in terms of reduction of skin lesions but they also required less symptomatic treatment than the control patients, indicating that longer-term follow-up studies should also focus on that issue. Thus, in some cases, tonsillectomy could become an adjunct to existing therapy, to reduce the dosage of drugs or allow the use of a less potent drug to control the disease. This becomes an interesting consideration in our era of expensive biological treatments. However, it remains to be seen how effective tonsillectomy is in the long term and exactly which patent groups will gain the most benefit.

\section{What's already known about this topic?}

- There is a well-established association between streptococcal tonsillitis and psoriasis, yet studies on the efficacy of tonsillectomy for psoriasis have never been afforded mainstream attention.

\section{What does this study add?}

- We have reviewed tonsil immunology and how tonsil infection could lead to skin disease.

- We have also reviewed all available reports of the outcome of tonsillectomy on psoriasis, including a recent observer-blinded prospective study, and identified patients who may potentially benefit from this procedure.

\section{References}

1 Christophers E. Psoriasis - epidemiology and clinical spectrum. Clin Exp Dermatol 2001; 26:314-20.

2 Krueger G, Koo J, Lebwohl $\mathrm{M}$ et al. The impact of psoriasis on quality of life: results of a 1998 National Psoriasis Foundation patient-membership survey. Arch Dermatol 2001; 137:280-4.

3 Valdimarsson H, Baker BS, Jónsdóttir I et al. Psoriasis: a T-cell-mediated autoimmune disease induced by streptococcal superantigens? Immunol Today 1995; 16:145-9.

4 Ellis $\mathrm{CN}$, Krueger GG. Treatment of chronic plaque psoriasis by selective targeting of memory effector T lymphocytes. N Engl J Med 2001; 345:248-55.

5 Gudjonsson JE, Johnston A, Sigmundsdottir H et al. Immunopathogenic mechanisms in psoriasis. Clin Exp Immunol 2004; 135:1-8.

6 Gottlieb SL, Gilleaudeau P, Johnson R et al. Response of psoriasis to a lymphocyte-selective toxin (DAB389IL-2) suggests a primary immune, but not keratinocyte, pathogenic basis. Nat Med 1995; $1: 442-7$.

7 Bos JD, van Joost TH, Powles AV et al. Use of cyclosporin in psoriasis. Lancet 1989; 334:1500-2.

8 Conrad C, Boyman O, Tonel G et al. Alpha1beta1 integrin is crucial for accumulation of epidermal $\mathrm{T}$ cells and the development of psoriasis. Nat Med 2007; 13:836-42. 
9 Valdimarsson H, Thorleifsdottir RH, Sigurdardottir SL et al. Psoriasis - as an autoimmune disease caused by molecular mimicry. Trends Immunol 2009; 30:494-501.

10 Johnston A, Gudjonsson JE, Sigmundsdottir H et al. Peripheral blood $\mathrm{T}$ cell responses to keratin peptides that share sequences with streptococcal $\mathrm{M}$ proteins are largely restricted to skin-homing CD8 T cells. Clin Exp Immunol 2004; 138:83-93.

11 Sigmundsdottir H, Sigurgeirsson B, Troye-Blomberg M et al. Circulating $\mathrm{T}$ cells of patients with active psoriasis respond to streptococcal M-peptides sharing sequences with human epidermal keratins. Scand J Immunol 1997; 45:688-97.

12 Gudmundsdottir AS, Sigmundsdottir H, Sigurgeirsson B et al. Is an epitope on keratin 17 a major target for autoreactive $\mathrm{T}$ lymphocytes in psoriasis? Clin Exp Immunol 1999; 117:580-6.

13 Shen Z, Wang G, Fan J-Y et al. HLA DR B1*04, *07-restricted epitopes on keratin 17 for autoreactive $\mathrm{T}$ cells in psoriasis. J Dermatol Sci 2005; 38:25-39.

14 Perry M, Whyte A. Immunology of the tonsils. Immunol Today 1998; 19:414-21.

15 MacLennan IC, Gulbranson-Judge A, Toellner KM et al. The changing preference of $\mathrm{T}$ and $\mathrm{B}$ cells for partners as T-dependent antibody responses develop. Immunol Rev 1997; 156:53-66.

16 Stent G, Reece JC, Baylis DC et al. Heterogeneity of freshly isolated human tonsil dendritic cells demonstrated by intracellular markers, phagocytosis, and membrane dye transfer. Cytometry 2002; 48:16776.

17 Summers KL, Hock BD, McKenzie JL et al. Phenotypic characterization of five dendritic cell subsets in human tonsils. Am J Pathol 2001; 159:285-95.

18 Steinman RM, Hemmi H. Dendritic cells: translating innate to adaptive immunity. Curr Top Microbiol Immunol 2006; 311:17-58.

19 Koch RJ, Brodsky L. Qualitative and quantitative immunoglobulin production by specific bacteria in chronic tonsillar disease. Laryngoscope 1995; 105:42-8.

20 Hope-Simpson RE. Streptococcus pyogenes in the throat: a study in a small population, 1962-1975. J Hyg (Lond) 1981; 87:10929.

21 Brodsky L, Moore L, Stanievich JF, Ogra PL. The immunology of tonsils in children: the effect of bacterial load on the presence of B- and T-cell subsets. Laryngoscope 1988; 98:93-8.

22 Fry L. Psoriasis. Br J Dermatol 1988; 119:445-61.

23 Telfer NR, Chalmers RJ, Whale K, Colman G. The role of streptococcal infection in the initiation of guttate psoriasis. Arch Dermatol 1992; 128:39-42.

24 Gudjonsson JE, Thorarinsson AM, Sigurgeirsson B et al. Streptococcal throat infections and exacerbation of chronic plaque psoriasis: a prospective study. Br J Dermatol 2003; 149:530-4.

25 Wardrop P, Weller R, Marais J, Kavanagh G. Tonsillitis and chronic psoriasis. Clin Otolaryngol Allied Sci 1998; 23:67-8.

26 Rasmussen JE. The relationship between infection with group A beta hemolytic streptococci and the development of psoriasis. Pediatr Infect Dis J 2000; 19:153-4.

27 Mrowietz U. Pustular eruptions of palms and soles. In: Fitzpatrick's Dermatology in General Medicine (Fitzpatrick TB, Wolff K, eds), 7th edn, Vol. 1. New York: McGraw-Hill Medical, 2008; 215-18.

28 Yokoyama M, Hashigucci K, Yamasaki Y. Effect of tonsillectomy in patients with pustulosis palmaris et plantaris. Acta Otolaryngol 2004; 124:1109-10.

29 Thorleifsdottir RH, Sigurdardottir SL, Sigurgeirsson B et al. Improvement of psoriasis after tonsillectomy is associated with a decrease in the frequency of circulating $\mathrm{T}$ cells that recognize streptococcal determinants and homologous skin determinants. J Immunol 2012; 188:5160-5.
30 Harabuchi Y, Takahara M, Kishibe $\mathrm{K}$ et al. Tonsil immunity and efficacy of tonsillectomy for tonsil focal infections. Int Congr Ser 2003; 1257:55-9.

31 Leung DY, Gately M, Trumble A et al. Bacterial superantigens induce $\mathrm{T}$ cell expression of the skin-selective homing receptor, the cutaneous lymphocyte-associated antigen, via stimulation of interleukin 12 production. J Exp Med 1995; 181:747-53.

32 Sigmundsdottir H, Gudjonsson JE, Valdimarsson H. Interleukin-12 alone can not enhance the expression of the cutaneous lymphocyte associated antigen (CLA) by superantigen-stimulated T lymphocytes. Clin Exp Immunol 2003; 132:430-5.

33 Picker LJ, Treer JR, Ferguson-Darnell B et al. Control of lymphocyte recirculation in man. II. Differential regulation of the cutaneous lymphocyte-associated antigen, a tissue-selective homing receptor for skin-homing T cells. J Immunol 1993; 150:1122-36.

34 Sigmundsdottir H, Gudjonsson JE, Jonsdottir I et al. The frequency of CLA+ CD8 + T cells in the blood of psoriasis patients correlates closely with the severity of their disease. Clin Exp Immunol 2001; 126:365-9.

35 Diluvio L, Vollmer S, Besgen P et al. Identical TCR beta-chain rearrangements in streptococcal angina and skin lesions of patients with psoriasis vulgaris. J Immunol 2006; 176:7104-11.

36 Winfield JM. Psoriasis as a sequel to acute inflammations of the tonsils: a clinical note. J Cutan Dis 1916; 34:441-3.

37 Norrlind R. Psoriasis following infections with hemolytic streptococci. Acta Derm Venereol 1950; 30:64-72.

38 Tulkens PM. Intracellular distribution and activity of antibiotics. Eur J Clin Microbiol Infect Dis 1991; 10:100-6.

39 LaPenta D, Rubens C, Chi E et al. Group A streptococci efficiently invade human respiratory epithelial cells. Proc Natl Acad Sci USA 1994; 91:12115-19.

40 Osterlund A, Popa R, Nikkila T et al. Intracellular reservoir of Streptococcus pyogenes in vivo: a possible explanation for recurrent pharyngotonsillitis. Laryngoscope 1997; 107:640-7.

41 Foote PA Jr, Brook I. Penicillin and clindamycin therapy in recurrent tonsillitis. Effect of microbial flora. Arch Otolaryngol Head Neck Surg 1989; 115:856-9.

42 Brook I, Leyva F. The treatment of the carrier state of group A beta-hemolytic streptococci with clindamycin. Chemotherapy 1981; 27:360-7.

43 Orrling A, Stjernquist-Desatnik A, Schalen C. Clindamycin in recurrent group A streptococcal pharyngotonsillitis - an alternative to tonsillectomy? Acta Otolaryngol 1997; 117:618-22.

44 Brook I. Failure of penicillin to eradicate group A beta-hemolytic streptococci tonsillitis: causes and management. J Otolaryngol 2001; 30:324-9.

45 Owen CM, Chalmers RJ, O'Sullivan T et al. A systematic review of antistreptococcal interventions for guttate and chronic plaque psoriasis. Br J Dermatol 2001; 145:886-90.

46 Whyte HJ, Baughman RD. Acute guttate psoriasis and streptococcal infection. Arch Dermatol 1964; 89:350-6.

47 Cepicka W, Tielsch R. [Focal infections and psoriasis vulgaris]. Dermatol Wochenschr 1967; 153:193-9.

48 Nyfors A, Rasmussen PA, Lemholt K, Eriksen B. Improvement of recalcitrant psoriasis vulgaris after tonsillectomy. J Laryngol Otol 1976; 90:789-94.

49 Saita B, Ishii Y, Ogata K et al. Two sisters with guttate psoriasis responsive to tonsillectomy: case reports with HLA studies. J Dermatol $1979 ; 6: 185-9$.

50 Jenisch S, Henseler T, Nair RP et al. Linkage analysis of human leukocyte antigen (HLA) markers in familial psoriasis: strong disequilibrium effects provide evidence for a major determinant in the HLA-B/-C region. Am J Hum Genet 1998; 63:191-9. 
242 The role of the palatine tonsils in psoriasis, S.L. Sigurdardottir et al.

51 Hone SW, Donnelly MJ, Powell F, Blayney AW. Clearance of recalcitrant psoriasis after tonsillectomy. Clin Otolaryngol Allied Sci 1996; 21:546-7.

52 Kataura A, Tsubota $H$. Clinical analyses of focus tonsil and related diseases in Japan. Acta Otolaryngol Suppl 1996; 523: 161-4.

53 Rosenberg EW, Skinner RB, Noah PW. Anti-infectious therapy in psoriasis. in: Psoriasis (Roenigk HH, Maibach HI, eds), 3rd edn. New York: Marcel Dekker, 1998; 373-9.

54 McMillin BD, Maddern BR, Graham WR. A role for tonsillectomy in the treatment of psoriasis? Ear Nose Throat J 1999; 78:155-8.

55 Ozawa A, Ohkido M, Haruki Y et al. Treatments of generalized pustular psoriasis: a multicenter study in Japan. J Dermatol 1999; 26: 141-9.
56 Takahara M, Bandoh N, Imada M et al. Efficacy of tonsillectomy on psoriasis and tonsil histology. Nihan Jibiinkoka Gakkai Kaiho. [Jpn Otorhinolar Soc J] 2001; 104:1065-70.

57 Elder JT, Bruce AT, Gudjonsson JE et al. Molecular dissection of psoriasis: integrating genetics and biology. J Invest Dermatol 2010; 130:1213-26.

58 Papp KA, Langley RG, Lebwohl $M$ et al. Efficacy and safety of ustekinumab, a human interleukin-12/23 monoclonal antibody, in patients with psoriasis: 52-week results from a randomised, double-blind, placebo-controlled trial (PHOENIX 2). Lancet 2008; 371:1675-84.

59 Suarez-Farinas M, Shah KR, Haider AS et al. Personalized medicine in psoriasis: developing a genomic classifier to predict histological response to Alefacept. BMC Dermatol 2010; 10:1. 